\title{
1 Duration and nature of the end-Cryogenian (Marinoan) glaciation
}

$2 \quad{ }^{1}$ Anthony R. Prave, ${ }^{2}$ Daniel J. Condon, ${ }^{3}$ Karl Heinz Hoffmann, ${ }^{2}$ Simon Tapster, and ${ }^{4}$ Anthony

3 E. Fallick

$4{ }^{1}$ Department of Earth and Environmental Sciences, University of St Andrews, St Andrews, KY16

$59 A L, U K$

$6 \quad{ }^{2}$ NERC Isotope Geosciences Laboratory, British Geological Survey, Nottingham, NG12 5GG, UK

$7 \quad{ }^{3}$ Geological Survey of Namibia, 1 Aviation Road, Windhoek, Namibia

$8{ }^{4}$ Scottish Universities Environmental Research Centre, East Kilbride, G75 0QF, UK

9

\section{ABSTRACT}

The end-Cryogenian glaciation (Marinoan) was Earth's last global glaciation yet its duration and character remain uncertain. Here we report $\mathrm{U}-\mathrm{Pb}$ zircon ages for two discrete ash beds within glacimarine deposits from widely separated localities of the Marinoan-equivalent Ghaub Formation in Namibia: $639.29 \pm 0.26 / 0.31 / 0.75 \mathrm{Ma}$ and $635.21 \pm 0.59 / 0.61 / 0.92 \mathrm{Ma}$. These findings, for the first time, verify the key prediction of the Snowball Earth hypothesis for the Marinoan glaciation: longevity, with a duration of $\geq 4.08 \pm 0.64 \mathrm{Myr}$. They also show that glacigenic sedimentation, erosion, and at least intermittent open-water conditions occurred 4 million years prior to termination of the Marinoan glaciation and that the interval of non-glacial conditions between the two Cryogenian glaciations was 20 Myr or less.

\section{INTRODUCTION}

The Cryogenian Period (c. $720-635 \mathrm{Ma}$ ) was marked by the two most severe glaciations in Earth history (Hoffman et al., 1998; Fairchild and Kennedy, 2007), the older Sturtian and younger Marinoan, and their association with unique lithofacies of cap carbonates (Kennedy et al., 2001; Hoffman and Schrag, 2002; Hoffman et al., 2011), stable isotope fluctuations (carbon, oxygen, boron, calcium; Halverson et al., 2005; Kasemann et al., 2005; Bao et al., 2008) and banded iron formation are evidence for global-scale environmental changes with postulated links to ocean- 
atmosphere oxygenation and biosphere evolution (Butterfield, 2009; Och and Sjields-Zhou, 2012; Sperling et al., 2013). Creation of a unified theory explaining those phenomena, however, has been hampered by one key obstacle: a lack of temporal constraints. Recently, the Sturtian was shown to have spanned an astonishing $56 \mathrm{Myr}$, from about $716 \mathrm{Ma}$ to $660 \mathrm{Ma}$ (Bowring et al., 2007;

Macdonald et al., 2010; Rooney et al., 2014; Rooney et al., 2015). In contrast, the duration of the Marinoan is unresolved: it terminated at c. $635 \mathrm{Ma}$ (Hoffmann et al. 2004; Calver et al., 2004; Condon et al., 2005; Zhang et al., 2008) but its initiation can only be stated as being younger than interglacial strata, which in Mongolia have been dated as c. $659 \mathrm{Ma}$ (Rooney et al., 2014) and in China as c. $655 \mathrm{Ma}$ (Zhang et al., 2008). Here we report new dates for the Marinoan-equivalent Ghaub Formation in Namibia that provide a basis for assessing the timing and nature of Earth's last global glaciation.

\section{GEOLOGY: SAMPLES DW-1 AND NAV-00-2B}

The Nosib, Otavi and Mulden Groups comprise the Neoproterozoic sedimentary record of the Congo craton in northern Namibia (Fig. 1). The Otavi Group (and correlative rocks in the Swakop Group of the Outjo and Swakop Zones) is a 2-5 km thick carbonate platform-slope-basin succession formed in the tropics along the margin of the Congo Craton. It is punctuated by two Cryogenian glacial units (Hoffmann and Prave, 1996; Hofman and Halverson, 2008), the older Chuos and the younger Ghaub formations and their respective cap carbonates, the Rasthof and Keilberg formations. U-Pb zircon ages on igneous and volcanic units provide geochronological constraints (see Fig. 1) that bracket deposition of the glacigenic-bearing strata in the Otavi Group to between c. $756 \mathrm{Ma}$ and $635 \mathrm{Ma}$.

One of the most informative exposures of the Ghaub Formation in northern Namibia is along Fransfontein Ridge (Fig. 1). There, the Ghaub rocks vary in thickness from 1 to $600 \mathrm{~m}$ and can be traced continuously for $c .70 \mathrm{~km}$; they consist mostly of stratified and massive carbonateclast-rich diamictite, minor intervals of rippled and cross-stratified dolomitic grainstone, marl and shale, and an upper unit, the 1 to $15 \mathrm{~m}$ thick Bethanis member (Hoffman and Halverson, 2008) 
typified by $\mathrm{cm}$ - to dem-thick stratified diamictite and grainstone-mudstone, all with abundant variably sized dropstones. Detailed studies (Hoffman and Halverson, 2008; Domack and Hoffmann, 2011) of those lithofacies have interpreted them as a succession of moraine and glacimarine sediments deposited along the margin of a repeatedly advancing and back-stepping ice-grounding line (Domack and Hoffmann, 2011).

Along Fransfontein Ridge, the diamictite-dominated Ghaub Formation contains lenses, generally a few metres thick, consisting of graded grainstone and laminated to massive calcareousdolomitic marl-shale with stringers of dropstones. At Duurwater (Fig. 2) one of these lenses about $15 \mathrm{~m}$ below the base of the Keilberg cap dolostone contains a prominent ash bed, sampled as DW-1 (Fig. 3). The DW-1 ash bed is $0.3 \mathrm{~m}$ thick, pale tan to pale yellow in colour, characterised by sharp upper and lower contacts, displays a slight fining-upward grading, contains rare disseminated quartz spar crystals and is overlain and underlain by IRD beds (Fig. 4A). These features indicate that this bed is an air-fall tuff contemporaneous with deposition of the glacimarine sediments, hence its age would also be the age of sedimentation for this part of the Ghaub Formation. Below the DW-1 ash bed is $10-15 \mathrm{~m}$ of massive diamictite and then a more than 100 -m-thick succession of carbonate rhythmite, breccia, laminated marl and shale with dispersed dropstones and isolated metre-scale and larger blocks derived from pre-Ghaub formation units. These lithofacies fill a steep-sided incision cut into the pre-Ghaub stratigraphy (Figs. 2, 3); in places along the Fransfontein outcrop belt as much as $300 \mathrm{~m}$ of strata have been cut out along this surface.

\section{Sample NAV-00-2B comes from an ash bed in the basinal equivalent of the Ghaub} Formation $c .30 \mathrm{~m}$ below the contact with the Keilberg cap dolostone at Navachab in central Namibia (Fig. 3). This occurrence was reported by Hoffman et al. (2004) and readers are referred to that paper for details.

\section{METHODS AND RESULTS}

All zircon dates in this study were obtained using established chemical abrasion (CA) isotope dilution thermal ionisation mass spectrometry (ID-TIMS) methods at the NERC Isotope 
Geoscience Laboratory of the British Geological Survey (Noble et al., 2015; see Data Repository for details). U-Pb dates have been determined relative to the gravimetrically calibrated EARTHTIME mixed U/Pb tracers (Condon et al., 2015; McLean et al., 2015) and ${ }^{238} \mathrm{U}$ and ${ }^{235} \mathrm{U}$ decay constants (Jaffey et al., 1971; Mattinson, 2010).

Sample DW-1 yielded a population of zircons with a consistent morphology (aspect ratio $\sim 2$ and long axis typically 200 to $300 \mu \mathrm{m}$ ) and colour. Ten zircons were dated by CA-ID-TIMS; U-Pb data for each analysis are concordant when the uncertainty in the ${ }^{238} \mathrm{U}$ and ${ }^{235} \mathrm{U}$ decay constants (Mattinson, 2010) are considered (Fig. 4B; Data Repository Table 1). All analyses yield a weightedmean ${ }^{207} \mathrm{~Pb} /{ }^{206} \mathrm{~Pb}$ date of $639.1 \pm 1.7 / 1.8 / 5.0(\mathrm{n}=10, \mathrm{MSWD}=1.08)$. Of those, one analysis has dispersion beyond that expected due to analytical scatter (see Data Repository) and is an obvious outlier with a U-Pb date younger than the main population. Excepting this grain, the other nine analyses yield a weighted mean ${ }^{206} \mathrm{~Pb} /{ }^{238} \mathrm{U}$ date of $639.29 \pm 0.26 / 0.31 / 0.75 \mathrm{Ma}(95 \%$ confidence interval, $\mathrm{n}=9, \mathrm{MSWD}=2.6$ ), which we interpret as the age of deposition. Sample NAV-00-2B is an aliquot of the sample dated previously as $635.5 \pm 1.2 \mathrm{Ma}$ (Hoffmann et al., 2004) at the Massachusetts Institute of Technology. Re-analysis of this sample was done to capitalise on the use of CA for the effective elimination of Pb-loss (Mattinson, 2005) and the EARTHTIME tracer and its comprehensive gravimetric calibration and uncertainty model (Condon et al., 2015; McLean et al., 2015). The ${ }^{206} \mathrm{~Pb} /{ }^{238} \mathrm{U}$ date for NAV-00-2B derived in this study is $635.21 \pm 0.59 / 0.61 / 0.92 \mathrm{Ma}(95 \%$ confidence interval, $\mathrm{n}=5, \mathrm{MSWD}=3.4$; Fig. 4B, Data Repository Table 2). This date is based upon a subset of the analyses (as explained in the Data Repository) and, even given improved analytical precision and accuracy, is indistinguishable from the date published in Hoffmann et al. (2004).

\section{DISCUSSION}

The $639.29 \pm 0.26 / 0.31 / 0.75 \mathrm{Ma}$ age for the DW-1 ash bed at Duurwater and the revised age of 635.21 $\pm 0.59 / 0.61 / 0.92 \mathrm{Ma}$ for the NAV-00-2B ash bed at Navachab now, for the first time, confirm that the Marinoan glaciation was long-lived, lasting at least $4.08 \pm 0.64 \mathrm{Myr}$. This verifies 
the key prediction of the Snowball Earth hypothesis for a long duration glaciation. The revised age

106 for NAV-00-2B also refines and reconfirms that the timing of termination of the Marinoan glaciation was synchronous worldwide (i.e. within error of the age data), occurring between 635.21 $\pm 0.59 / 0.61 / 0.92 \mathrm{Ma}$ and $635.2 \pm 0.5 \mathrm{Ma}$, the age of an ash bed in the lower part of the cap carbonate sequence in China (Condon et al., 2005); a conclusion reinforced by the U-Pb zircon age of $636.41 \pm 0.45 \mathrm{Ma}$ for a volcaniclastic unit in the glacial-cap carbonate transition in Tasmania

111 (Calver et al., 2004).

Since the debut of the Snowball Earth hypothesis, debate has ensued regarding the extent of

113 land and sea ice during Cryogenian glaciations, the causes of repetitive patterns of inferred

114 proximal-distal and advance-retreat deposits, and the overall timing and duration of glacial

115 sedimentation (e.g. see discussion by Spence et al., 2016, and references therein). Further, the lack 116 of well-defined age models has led to an array of climate state and sedimentation scenarios, ranging 117 from surmising that the Marinoan rock record formed by glacial-interglacial-scale epochs (e.g.

118 Allen and Etienne, 2008; LeHeron et al., 2011) to interpretations of the bulk of that record as

119 having been deposited during a brief interval of time near to the end of the glacial state (e.g. Benn et 120 al., 2015). Although these interpretations are not necessarily mutually exclusive, assessing them 121 remains speculative because of the lack of constraints for the absolute timing of sedimentation. Our 122 new geochronological data provide a better temporal framework for understanding the Marinoan 123 glaciation. For example, the $c .639 \mathrm{Ma}$ DW-1 ash bed occurring above a $c .100$-m-thick glacimarine 124 succession shows that glacial erosion and sediment accumulation concurrent with at least 125 intermittent open-water conditions in the tropics existed more than 4 million years before the 126 ultimate meltback phase of the Marinoan ice sheets. This impacts on a range of issues regarding the 127 Marinoan climate state: it provides constraints and corroboration of models that yield results 128 consistent with such conditions, including predictions of plausible $\mathrm{CO}_{2}$ levels permissive of 129 enabling ice-line migration and associated sedimentation in the tropics, as documented for the 130 Ghaub Formation (e.g. Domack and Hoffman, 2011), to considerations of low-latitude refugia and 
131 the survival of eukaryotic organisms within the main phase of the Marinoan glaciation. Further,

132 given our new age that provides a minimum duration for the Marinoan glaciation and the c. $660 \mathrm{Ma}$

133 age for the end of the older Cryogenian glaciation (Sturtian), the intervening interglacial interval

134 and associated biogeochemical and isotopic events represent a timespan of 20 Myr or less (Fig. 4C).

135 Determining how and why this period of non-glacial conditions punctuated an otherwise apparently 136 consistently and largely ice-covered Earth poses an intriguing research question.

\section{CONCLUSION}

The 639.1 $\pm 1.7 / 1.8 / 5.0 \mathrm{Ma}$ age obtained on an ash bed in glacimarine sediments of the

140 Marinoan-equivalent Ghaub Formation in northern Namibia combined with a refined age of 635.21

$141 \pm 0.59 / 0.61 / 0.92 \mathrm{Ma}$ for an ash bed in the basinal equivalent of the Ghaub Formation in central

142 Namibia confirm that the Marinoan glaciation was long-lived, at least $4 \mathrm{Myr}$ in duration, and that

143 the preceding interval of non-glacial conditions was less than $20 \mathrm{Myr}$ in duration. Our data also

144 confirm that the sedimentary archive of the Marinoan glaciation records glacial erosion-

145 sedimentation and at least intermittent open-water conditions as much as 4 million years prior to 146 terminal meltback at c. $635 \mathrm{Ma}$.

ACKNOWLEDGMENTS

This work was supported by NIGFSC grant IP XXXXX.

\section{REFERENCES CITED}

152 Allen, P.A., and Etienne, J.L., 2008, Sedimentary challenge to Snowball Earth: Nature Geosciences, v. 1, p. $817-825$.

154 Bao, H., Lyons, J.R., and Zhou, C., 2008, Triple oxygen isotope evidence for elevated CO2 levels after a Neoproterozoic glaciation: Nature, v. 453, p. 504-506. 
Benn, D.I., Le Hir, G., Bai, H., Donnadieu, Y., Dumas, C., Fleming, E.J., Hambrey, M.J., McMillan, E.A., Petronis, M.S., Ramstein, G, Stevenson, C.T.E., Wynn, P.M., Fairchild, I.J., 2015, Orbitally forced ice sheet fluctuations during the Marinoan Snowball Earth glaciation: Nature Geoscience, v. 8, p. 704-707.

Bowring, S.A., Grotzinger, J.P., Condon, J., Ramezani, J., Newall, M.J., and Allen, P.A., 2007, Geochronologic constraints of the chronostratigraphic framework of the Neoproterozoic Huqf Supergroup, Sultanate of Oman: American Journal of Science, v. 307, p. 1097-1145.

Butterfield, N.J., 2009, Oxygen, animals and oceanic ventilation: an alternative view: Geobiology, v. 7, p. 1-7.

Calver, C.R., Black, L.P., Everard, J.L., and Seymour, D.B., 2004, U-Pb zircon age constraints on late Neoproterozoic glaciation in Tasmania: Geology, v. 32, p. 893-896.

Condon, D.J., Schoene, B., McLean, N.M., Bowring, S.A., and Parrish, R.R., 2015, Metrology and traceability of $\mathrm{U}-\mathrm{Pb}$ isotope dilution geochronology (EARTHTIME Tracer Calibration Part I): Geochimica et Cosmochimica Acta, v. 164, p. 464-480,

Condon, D., Zhu, M., Bowring, S., Wang, W., Yang, A., and Jin, Y., 2005, U-Pb ages from the Neoproterozoic Doushantuo formation, China: Science, v. 308, p. 95-98.

Cox, G.M., Strauss, J.V., Halverson, G.P., Schmitz, M.D., McClelland, W.C., Stevenson, R.S., and Macdonald, F.A., 2015, Kikiktat volcanics of Arctic Alaska - melting of harzburgitic mantle associated with the Franklin large igneous province: Lithosphere L435-1. DOI: 10.1130/L435.1.

Domack, E.W., and Hoffman, P.F., 2011, An ice grounding-line wedge from the Ghaub glaciation (635 Ma) on the distal foreslope of the Otavi carbonate platform, Namibia, and its bearing on the snowball Earth hypothesis: Geological Society of America Bulletin, v. 123, p. 1448-1477. Fairchild, I.J., and Kennedy, M.J., 2007, Neoproterozoic glaciation in the Earth System: Journal of the Geological Society, v. 164, p. 895-921. 
Halverson, G.P., Hoffman, P.F., Schrag, D.P., Maloof, A.C., and Rice, A.H.N., 2005, Toward a Neoproterozoic composite carbon-isotope record: Geological Society of America Bulletin, v. 117, p. 1181-1207.

Hoffman, P.F., 2011, Strange bedfellows: glacial diamictite and cap carbonate from the Marinoan (635 Ma) glaciation in Namibia: Sedimentology, v. 58, p. 57-119.

Hoffman, P.F., and Halverson, G.P., 2008, Otavi Group of the western Northern Platform, the eastern Kaoko Zone and the Northern Margin Zone, in Miller, R.McG., ed., The Geology of Namibia: Volume 2 Neoproterozoic to Lower Palaeozoic: Ministry of Mines and Energy, Namibia, p. 13-69-13-136.

Hoffman, P.F., Hawkins, D.P., Isachsen, C.E., and Bowring, S.A., 1996, Precise U-Pb zircon ages for early Damaran magmatism in the Summas Mountains and Weltwischia Inlier, northern Damara Belt, Namibia. Communications of the Geological Survey of Namibia 11, 47-52.

Hoffman, P.F., Kaufman, A.J., Halverson, G.P., and Schrag, D.P., 1998, A Neoproterozoic snowball Earth: Science, v. 281, p. 1342-1346.

Hoffman, P.F., and Schrag, D.P., 2002, The snowball Earth hypothesis: testing the limits of global change: Terra Nova, v. 14, p. 129-155.

Hoffmann, K.H., Condon, D., Bowring, S., and Crowley, J., 2004, U-Pb zircon date from the Neoproterozoic Ghaub Formation, Namibia: constraints on Marinoan glaciation: Geology, v. 32, p. $817-821$.

Hoffmann, K.H., and Prave, A.R., 1996, A preliminary note on a revised subdivision and regional correlation of the Otavi Group based on glacigenic diamictites and associated cap dolostones: Communications of the Geological Survey of Namibia, v. 11, p. 77-82.

Jaffey, A.H., Flynn, K.F., Glendenin, L.E., Bentley, W.C., and Essling, A.M., 1971, Precision measurement of half-lives and specific of ${ }^{235} \mathrm{U}$ and ${ }^{238} \mathrm{U}$ : Physics Reviews C4, p. 1889-1906. 
Kasemann, S.A., Hawkesworth, C.J., Prave, A.R., Fallick, A.E., and Pearson, P.N., 2005, Boron and calcium isotope composition in Neoproterozoic carbonate rocks from Namibia: evidence for extreme environmental change: Earth and Planetary Science Letters, v. 231, p. 73-86.

Kennedy, M.J., Christie-Blick, N., and Prave, A.R., 2001, Carbon isotopic composition of Neoproterozoic glacial carbonates as a test of paleoceanographic models for snowball Earth phenomena: Geology, v. 29, p. 1135-1138.

Le Heron, D.P, Cox, G., Trundley, A., and Collins, A.S., 2011, Two Cryogenian glacial successions compared: Aspects of the Sturt and Elatina sediment records of South Australia: Precambrian Research, v. 186, p. 147-168.

Macdonald, F.A., Schmitz, M.D., Crowley, J.L., Roots, C.F., Jones, D.S., Maloof, A.C., Strauss, J.V., Cohen, P.A., Johnston, D.T., and Schrag, D.P. 2010, Calibrating the Cryogenian: Science, v. 327, p. 1241-1243.

Mattinson, J.M., 2005, Zircon U-Pb chemical abrasion ("CA-TIMS") method: Combined annealing and multi-step partial dissolution analysis for improved precision and accuracy of zircon ages: Chemical Geology, v. 220, p. 47-66.

Mattinson, J.M., 2010, Analysis of the relative decay constants of ${ }^{235} \mathrm{U}$ and ${ }^{238} \mathrm{U}$ by multi-step CA TIMS measurements of closed-system natural zircon samples: Chemical Geology, v. 275, p. 186-198.

McLean, N., Condon, D.J., Schoene, B., and Bowring, S.A., 2015, Evaluating Uncertainties in the Calibration of Isotopic Reference Materials and Multi-Element Isotopic Tracers (EARTHTIME Tracer Calibration Part II): Geochimica et Cosmochimica Acta, v. 164, p. 481-501.

Miller, R. McG., 2008, The Geology of Namibia: Neoproterozoic to lower Palaeozoic. Ministry of Mines and Energy, Geological Survey, Namibia. 
229 Noble, S.R., Condon, D.J., Carney, J.N., Wilby, P.R., Pharoah, T.C., and Ford, T.D., 2015, U-Pb geochronology and global context of the Charnian Supergroup, UK: Constraints on age of key Ediacaran fossil assemblages. Geological Society of America Bulletin, v. 127, p. 250-265.

Och, L.M. \& Shields-Zhou, G.A., 2012, The Neoproterozoic oxygenation event: Environmental perturbations and biogeochemical cycling: Earth-Science Reviews, v. 110, p. 26-57.

Rooney, A.D., Macdonald, F.A., Strauss, J.V., Dudás, F.Ö., Hallmann, C., and Selby, D., 2014, ReOs geochronology and coupled Os-Sr isotope constraints on the Sturtian snowball Earth: Proceedings of the National Academy of Sciences, v. 111, p. 51-56.

Rooney, A.D., Strauss, J.V., Brandon, A.D., and Macdonald, F.A., 2015, A Cryogenian chronology: Two long-lasting synchronous Neoproterozoic glaciations: Geology, v. 43, p. 459-462. 253-306.

Sperling, E.A., Halverson, G.P., Knoll, A.H., Macdonald, F.A., and Johnston, D.T., 2013, A basin redox transect at the dawn of animal life: Earth and Planetary Science Letters, v. 371-372, p. 143-155.

Zhang, S., Jiang, G., and Han, Y. 2008, The age of the Nantuo Formation and Nantuo glaciation in South China: Terra Nova, v. 20, p. 289-294.

Zhou, C., Tucker, R, Xiao, S., Peng, Z. Yuan, X. and Chen, Z., 2004, New constraints on the ages of Neoproterozoic glaciations in south China: Geology, v. 32, p. 437-440. 
251 Figure 1. Generalised geologic framework of northern Namibia. Ages for the Naauwpoort

252 Formation (NF) and Oas Syenite (OS) are from Hoffman et al. (1996), for the Ombombo Subgroup

253 from Halverson et al. (2005), and for the Ghaub Formation from Hoffmann et al. (2004) and this

254 paper. See Miller (2008, and references therein) for the ages of the granites that post-date the

255 Swakop Group rocks.

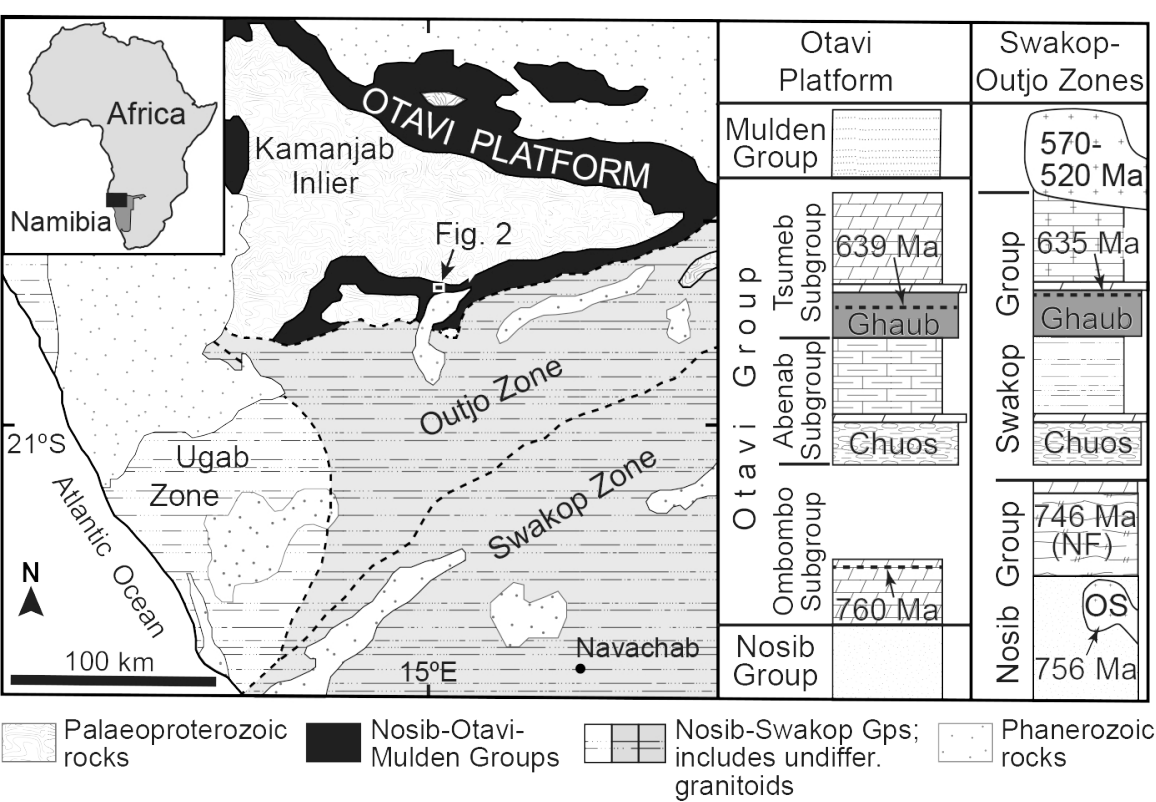

258 Figure 2. A. Fransfontein Ridge geology in the vicinity of sample DW-1. See Figure 1 for location.

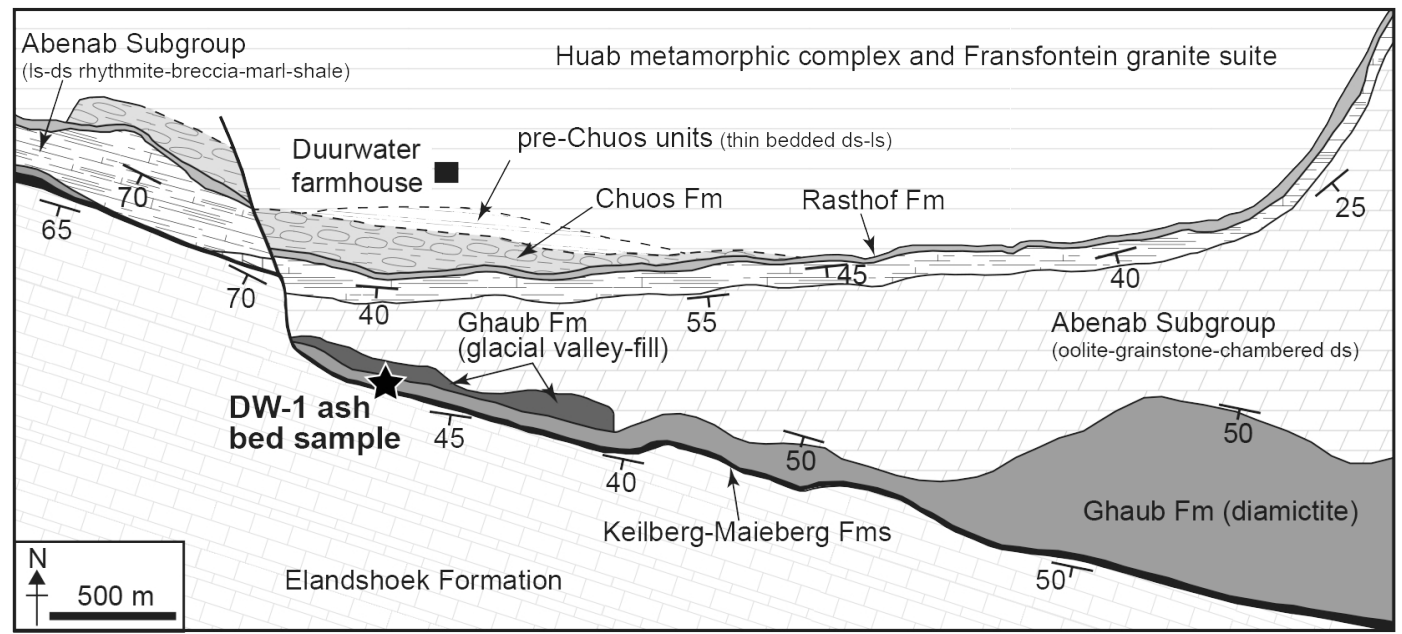


261 Figure 3. Simplified stratigraphy of the Duurwater and Navachab sections (for details of the

262 Navachab section see Hoffmann et al., 2004); left column is a detailed section showing the

263 stratigraphic position of the DW-1 ash bed within the diamictic interval of the Ghaub Formation.

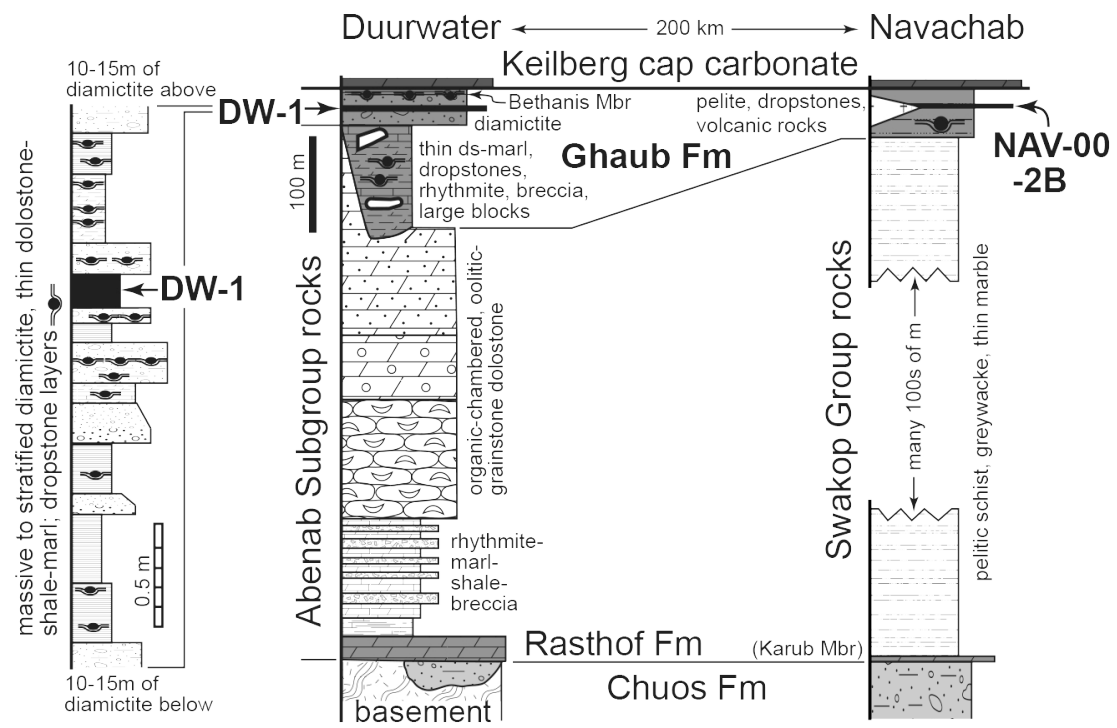


Figure 4. A. DW-1 ash bed between ice-rafted-debris beds, Duurwater section. B. U-Pb Concordia

267 plot of data for samples DW-1 and NAV-00-2B; solid ellipses represent analyses included in age

268 calculation, dashed ellipses are not included (see Data Repository for explanation). C.

269 Neoproterozoic timeline trends for key isotope proxy datasets: S isotopes after (from Och and

270 Shields-Zhou, 2012, and references therein); Sr and C isotopes after (Halverson et al., 2005) and

271 our own data. U-Pb age data from: 1-Cox et al. (2015), 2-Macdonald et al. (2010), 3-Zhou et al.

272 (2004), 4-Zhang et al. (2008), 5-Condon et al. (2005). Bold ages are reported herein.
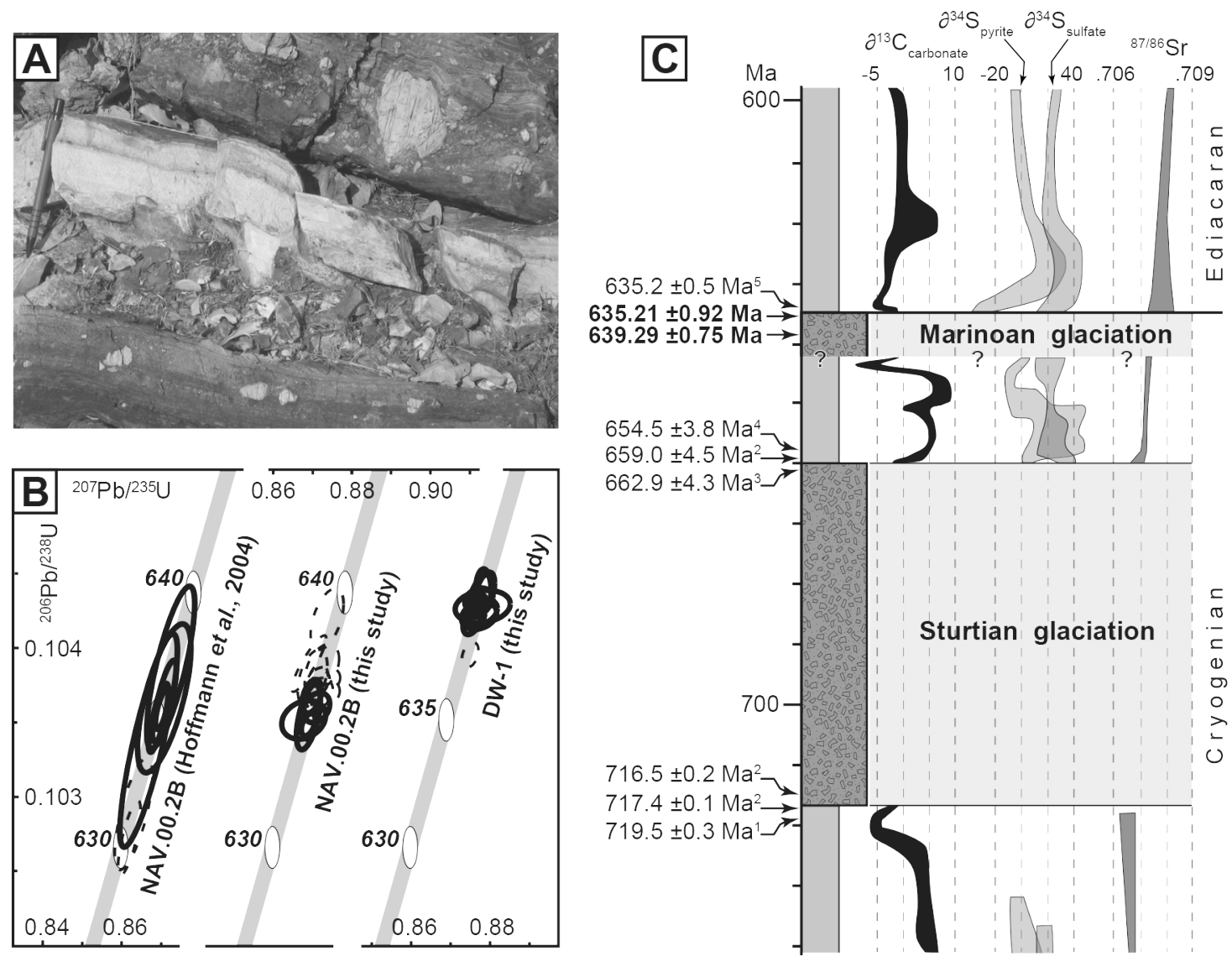